\title{
Expiratory Reserve Volume
}

National Cancer Institute

\section{Source}

National Cancer Institute. Expiratory Reserve Volume. NCI Thesaurus. Code C111200.

The maximum volume of air a subject can exhale from the lungs after a tidal exhalation. 